\title{
Production Risk of Seaweed Cultivation in South Sulawesi: Comparison between Cobb-Douglas and Just-Pope Production Function
}

\section{Nur Alam Kasim ${ }^{1}$, Megawati ${ }^{2}$, Arifah ${ }^{3}$, Wiwiek Hidayati ${ }^{4}$}

1 Fisheries Agribusiness Studies Program, Pangkep State Polytechnic of Agriculture South Sulawesi, Indonesia.

2 Fisheries Agribusiness Studies Program, Pangkep State Polytechnic of Agriculture South Sulawesi, Indonesia.

${ }^{3}$ International Business Administration Studies Program, Pangkep State Polytechnic of Agriculture South Sulawesi, Indonesia.

${ }^{4}$ International Business Administration Studies Program, Pangkep State Polytechnic of Agriculture South Sulawesi, Indonesia

*Corresponding author's e-mail: nuralamkasim@mail.polipangkep.ac.id

How to Cite: Kasim, N.A., Megawati., Arifah., Hidayati, W. (2019). Production Risk of Seaweed Cultivation in South Sulawesi: Comparison between Cobb-Douglas and Just-Pope Production Function. Int. J. Agr. Syst. 7(2): 127-137

\begin{abstract}
Fluctuation in production on farm of seaweed Eucheuma cottonii could be affected by climate, pests and diseases, input factors, management and socio-economic conditions of farmers. The objectives of this study were (1) analyzed determinants of productivity, (2) analyzed the factors that affected the risk of production, and (3) analyzed the factors that affected productivity after considering the risk of production. The samples used in this study were 210 seaweed farmers selected by using proportional random sampling method. Multiple linear regression model with Cobb-Douglas and Just-Pope production functions were used to analyze the data. The results showed that (1) Productivity of seaweed E. cottonii positively influenced by number of seeds, bond distance of seeds and labor; (2) area of lots, seeds and bond distance of seeds negatively effected the risk of production; and (3) area of lots, seeds, bond distance of seeds, labor, and experience of farmers positively effected the productivity after considering of risks whereas age of farmers affected negatively. Values of regression coefficient had significant affected the productivity of seaweed E. cottonii (Cobb-Douglas model) tended to decline after considering the risk of production (Just-Pope model). This implies that in analyzing seaweed productivity, it needs to consider the risks in the model.
\end{abstract}

Copyright @ 2019 IJAS. All rights reserved.

\section{Keywords:}

Seaweed; productivity; risk of production; just-pope

\section{Introduction}

South Sulawesi is one of centres of farming development of seaweed Eucheuma cottonii in Indonesia. Data from the Department of Marine and Fisheries of South Sulawesi (2010), the potential area for seaweed cultivation in South Sulawesi reaches \pm 193000 hectares and is utilized by $15 \%$ only. Production target of seaweed in South Sulawesi in 2010-2014 is about 2.43 million tons with production of seaweed during the period 
2005 to 2009 is only about $10.77 \%$ per year with a contribution of $32.01 \%(810.640$ tonnes) of national production in 2009 (Hidayati et al, 2014). Productivity of seaweed is still low, due to the potential of land that has not been used optimally and continously unstable production (Nurdjana, 2006).

During the period of 2009-2011, there are three centers of production of seaweed which has the highest volume of seaweed production in South Sulawesi (Table 1). The high production of seaweed from year to year during the period of 3 (three) years, largely due to the addition of land area.

Table 1. Volume of Production of Seaweed Cultivation of E. cottonii Highest in Three Districts in South Sulawesi, 2009-2011

\begin{tabular}{lrrrcc}
\hline \multicolumn{1}{c}{ Districts } & \multicolumn{1}{c}{2009} & \multicolumn{1}{c}{2010} & \multicolumn{1}{c}{2011} & Total (tonnes) & Growth $(\%)$ \\
\hline Takalar & 195,241 & 417,424 & 418,818 & $1,031,483$ & 66.237 \\
East Luwu & 15,040 & 183,202 & 196,361 & 394,603 & 25.339 \\
Bone & 18,616 & 55,899 & 56,660 & 131,175 & 8.424 \\
Total (tonnes) & 228,897 & 656,525 & 671839 & $1,557,261$ & 100.000 \\
\hline
\end{tabular}

Source: Department of Marine and Fisheries of South Sulawesi, 2012.

The period year 2007-2011, the development of the production of seaweed Eucheuma cottonii turns fluctuate. The production process takes place in the open and use the main energy source of sunlight (Nurdjana, 2006). Azwir (2011), the factors of production (input) has positive effects on the production and productivity of seaweed in Kendari is an area of lots, number of seeds, education of Farmers and dummy of location. Seaweed cultivation activities always deal with risk and uncertainty, which is an externalities factor that is difficult to be controlled by the farmers. Just (1974) and Just (1975), there are three sources of risk and uncertainty; (1) the risks associated with environmental health and technology; (2) risks related to market factors; and (3) the uncertainty associated with changes in government policy. Zakirin et al (2013) in the district of Pontianak, Indonesia using the model of the Just-Pope production function shows that the factors that affect the risk of rice production in tidal land is land and seeds with a negative influence. Roe and Tomasi (Sing et al., 1986 cit Senjawati, 2008) in the Dominican Republic showed that the risk of affecting the productivity of rice farming in the farmers' production decisions. If farmers are faced with the risk of high productivity, the ability to produce also be lower. According to Kay (1981) sources of risk and uncertainty in agriculture are the production and technical risks incurred by the technical relationship among output and input usage levels, price, financial, government policy, and individuals. Risk can be sourced in the business cycle, seasonal fluctuations, inflation, climate, pest, exchange rate, and technology (Widodo, 2006).

The aims of this study are to (1) analyze determinant factors of productivity (2) analyze the factors that affect the risk of production, and (3) analyze factors that affect productivity after considering the risk of production of seaweed E. cottonii in South Sulawesi. The expected benefit of this research is the realization of seaweed farming development policy which is aimed at improving productivity by considering the risk of production. 


\section{Method}

\subsection{Research Area and Data}

Research location was purposive by selected, with the consideration that this area is a center of development of seaweed and has the highest volume of seaweed production in South Sulawesi in 2009-2011. 210 respondent of seaweed farmers taken by a proportional random sampling from Takalar, East Luwu dan Bone Districts. Data was collected from May to October 2013.

\section{Cobb-Douglas Production Function Model}

The production function which is often employed as an analytical tool in studies using econometric approaches is the Cobb-Douglas production function (Yotopoulus and Nugent, 1976; Debertin, 1986; Nicholson, 1998). Mathematically the Cobb-Douglas production function is as follows:

$$
Y=A X_{1}^{b 1} X_{2}^{b 2} \ldots X_{i}^{b i} \ldots X_{n}^{b n} e^{u}
$$

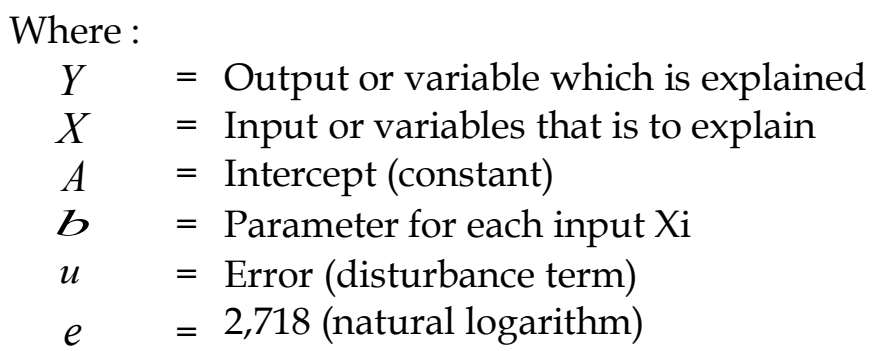

In order to estimate the Cobb-Douglas production function more easily, the equation

(1) needs to be previously changed into the following logarithmic form as follows:

$$
\log Y=\log A+b_{1} \log X_{1}+b_{2} \log X_{2}+b_{i} \log X_{i}+\ldots \ldots .+b_{n} \log X_{n}
$$

In logarithmic form, equation (2) can be estimated using the method of least squares (OLS), regression coefficient values or parameters can be searched (Gujarati, 1997). Cobb-Douglas production function is characterized by the magnitude of the elasticity of production for each production factor equal to the value of the input parameter and indicates the magnitude of the relationship between each factor of production to production (Hayami and Ruttan, 1985).

Estimation the determinant factors of productivity of seaweed used production function of Cobb-Douglas with the analysis model as follows:

$$
\begin{aligned}
\operatorname{Ln} Y= & a_{0}+a_{1} \ln L K V+a_{2} \ln B B T+a_{3} \ln T K+a_{4} \ln J I K T+a_{5} \ln J A B+a_{6} \ln U M R \\
& +a_{7} \ln \text { PDD }+a_{8} \ln \text { PGLMN }+\varepsilon
\end{aligned}
$$

Where :

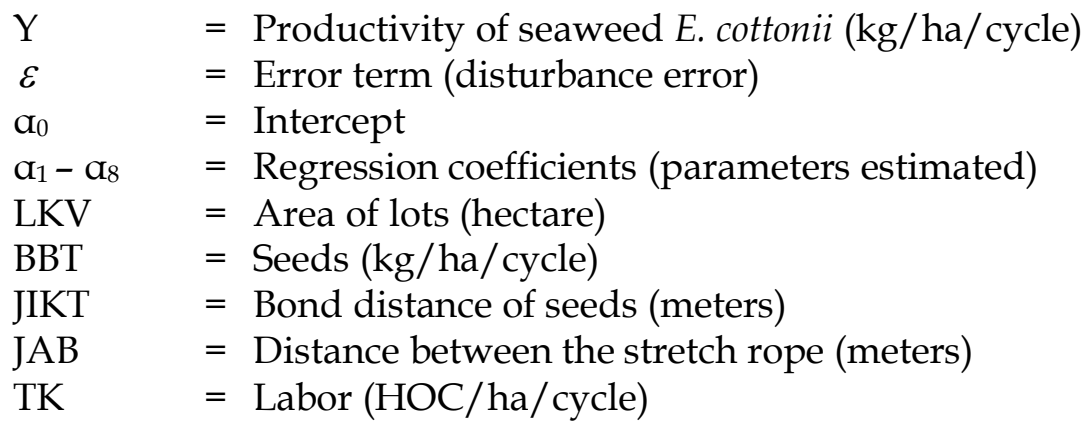




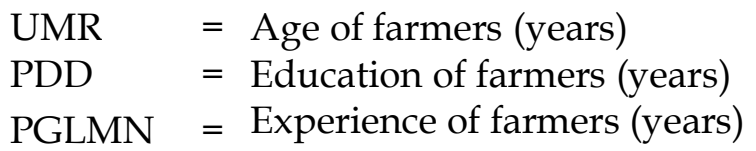

Test the validity of the data is used to test abberation assumption of classical and test suitability model (Gujarati, 1995; Pindyck and Rubinfeld, 2001). This study uses cross section data that is necessary to be tested of the classical assumption, namely nonmulticollinearity and homoskedastisitas. Testing inferential analysis include: the coefficient of determination $\left(\mathrm{R}^{2}\right)$, the F-test (over all tests), and tests to estimate the parameters (t-test).

\section{Just-Pope Production Function Model}

Just and Pope (Roumasset, 1976), formulated a stochastic production function in three forms :

$$
\begin{array}{ll}
q=F_{1}(X) \equiv f(x) e^{\varepsilon} & E(\varepsilon)=0 \\
q=F_{2}(X) \equiv f(x) \varepsilon & E(\varepsilon)=1 \\
q=F_{3}(X) \equiv f(x)+\varepsilon & E(\varepsilon)=0
\end{array}
$$

$$
\begin{array}{cl}
\text { Where: } & \\
q & =\text { Production } \\
f(x) & =\text { Production function of deterministic } \\
F_{i} & =\text { Production function of stochastic } \\
X & =\text { input vector } \\
\varepsilon & =\text { Stochastic disturbance variables }
\end{array}
$$

Specification of equation (4), (5), and (6) that, not considering the risk variable. If the risk variables considered, the specification of stochastic element can be improved. Repair specifications stochastic elements can be done, if the specification of the production function can consider the risk criteria. Production function which generally meets the criteria of risk has been developed by modifying the Just and Pope confounding variables $(\varepsilon)$ into a function of risk $h(H) e$, and add these functions to the production function that will be used to estimate (Roumasset, 1976). Through the modified function can know the relationship between the input to the output expectations at the same time can also be determined by the input relations of production risk.

According to Just and Pope (1979), the traditional production function (Cobb-Douglas) imply strict limits so that the production function becomes inflexible. These flaws, can be overcome by incorporating two functions: (a) the function that sets the influence input to output, and (b) a function that sets the input of the variants influence output (production risk). That function is (Just and Pope, 1979):

$y=f(X)+h^{1 / 2}(X) \varepsilon$

Where: $E(\varepsilon)=0$ dan $V(\varepsilon)=1$ 
The relationship between the Cobb-Douglas production function with equation (7), in a simple way can be formulated into:

$$
\begin{aligned}
& y=f^{*}(X) e^{\varepsilon}=f(X)+h^{1 / 2}(X) e \\
& E\left(\varepsilon^{*}\right)=E(\varepsilon)=0
\end{aligned}
$$

Where: $f(X) \equiv h^{1 / 2}(X) \equiv f^{*}(X) E\left(e^{\varepsilon}\right)$, dan $\varepsilon \equiv e^{\varepsilon}-E\left(e^{\varepsilon}\right)$. Thus, the form of the objective function is no longer restrictive, with the condition $f(X) \equiv h^{1 / 2}(X)$

Estimation the production risk of seaweed E. cottonii used production function of JustPope (1979) with stages as follows:

1. Estimating the production function of Cobb-Douglas with the method of NonLinear Least Squares (NLS) in order to obtain the disturbance error $\left(\varepsilon_{1}\right)$ as a proxy of the risk of production.

$$
\begin{aligned}
Y= & \operatorname{Exp}\left(a_{0}+a_{1} \ln L K V+a_{2} \ln B B T+a_{3} \ln T K+a_{4} \ln J I K T+a_{5} \ln J A B+a_{6} \ln \right. \\
& \text { UMR } \left.+a_{7} \ln \text { PDD }+a_{8} \ln \text { PGLMN }\right)+\varepsilon_{1}
\end{aligned}
$$

2. Disturbance error/risk of production in the estimation of the independent variables with the method of Ordinary Least Square (OLS).

$$
\begin{gathered}
\operatorname{Ln}\left|\varepsilon_{1}\right|=\beta_{0}+\beta_{1} \ln \mathrm{LKV}+\beta_{2} \ln \mathrm{BBT}+\beta_{3} \ln \mathrm{TK}+\beta_{4} \ln \mathrm{JIKT}+\beta_{5} \ln \mathrm{JAB}+\beta_{6} \ln \\
\mathrm{UMR}+\beta_{7} \ln \mathrm{PDD}+\beta_{8} \ln \mathrm{PGLMN}+\varepsilon_{2}
\end{gathered}
$$

Test the validity of the data is OLS method the same as in the production function of Cobb-Douglas.

Estimation the productivity of seaweed E. cottonii after considering the risks of production used a method of Just-Pope (1979) by method of estimating the production function of Cobb-Douglas with the method of Non-Linear Least Squares (NLS) with the residuals $\varepsilon_{2}$ that is resulted from the estimation of function risk of production, as the weighted (the divisor). Model of analysis as follows:

$$
\begin{aligned}
& \mathrm{Y}^{*}=\operatorname{Exp}\left(\delta_{0}+\delta_{1} \ln \mathrm{LL}^{*}+\delta_{2} \ln \mathrm{BBT}^{*}+\delta_{3} \ln \mathrm{TK}^{*}+\delta_{4} \ln \mathrm{JIKT}+\delta_{5} \ln \mathrm{JAB}+\delta_{6} \ln \right. \\
& \left.\quad \mathrm{UMR}+\delta_{7} \ln \mathrm{PDD}+\delta_{8} \ln \mathrm{PGLMN}\right)+\varepsilon_{3} \\
& \text { * }: \text { indicates weighted with } \varepsilon_{2}
\end{aligned}
$$

Test the validity of the data that is test suitability of model (Gujarati, 1995; Pindyck and Rubinfeld, 2001) include: the coefficient of determination $\left(\mathrm{R}^{2}\right)$, whereas hypothesis testing with the F-test (over all test) and test to estimate the parameters ( $\mathrm{t}$-test)

\section{Results and Discussion}

This section presents and discusses the data and results of the econometric analysis.

\subsection{Determinants of Productivity Seaweed E. cottonii}

The regression results of determinants of productivity seaweed using ordinary least squares (symptom-free multicolinearity and heteroscedasticity) are shown in Table 2. T-test results indicate that determinants of productivity of seaweed in South Sulawesi are number of seeds, bond distance of seeds, and labor. 
Increasing the amount of the number of seeds can increase productivity. The number of seeds have significantly and positive at $1 \%$. Regression coefficient of 0.362 indicates that an increase in the number of seeds by $1 \%$ will increase the productivity of seaweed by 0.362 percent.

The bond distance of seeds significaant effect and positive on the productivity of seaweed. Regression coefficient value is 0.241 , indicating that the increase in the bond distance of seeds by 1 percent would increase the productivity of seaweed of 0.241 percent.

Labor has highly significant and positive at 1\%. Regression coefficient value of labor of 0.226 , it means that an increase of labor usage by 1 percent, and it will increase productivity by 0.226 percent.

Table 2. Regression Estimates of Determinant Factors of Productivity Seaweed $E$. Cottonii (Symptom-free multicolinearity and heteroscedasticity)

\begin{tabular}{lccc}
\hline \multicolumn{1}{c}{ Variable } & Coefficient & $\begin{array}{c}\text { Standard } \\
\text { errors }\end{array}$ & t-Statistic \\
\hline Constant & $3.460^{* *}$ & 0.293 & 11.812 \\
Area of lots & 0.028 & 0.021 & 1.306 \\
Seeds & $0.362^{* * *}$ & 0.088 & 4.124 \\
Bond distance of seeds & $0.241^{* * *}$ & 0.060 & 4.006 \\
Distance between the stretch rope & 0.113 & 0.094 & 1.207 \\
Labor & $0.226^{* * *}$ & 0.041 & 5.454 \\
Age of farmers & 0.022 & 0.059 & 0.383 \\
Education of farmers & 0.051 & 0.032 & 1.613 \\
Experience of farmers & -0.029 & 0.025 & -1.162 \\
\hline $\mathrm{R}^{2}$ & 0.903 & & \\
$\mathrm{R}^{2}$ adjusted & 0.899 & & \\
\hline
\end{tabular}

Notes: ${ }^{*},{ }^{* *}{ }^{, * *}$ are levels of significant at 1,5 and 10 percent

\subsection{Factors Affecting Risk of Production Seaweed E. Cottonii}

The regression results of production risk of seaweed using ordinary least squares (symptom-free multicolinearity and heteroscedasticity) are shown in Table 3. Based on the results of the regression analysis in Table 2 could be explained that the $\mathrm{R}^{2}$ value of 0.31 indicates that 31 percent of variation in the dependent variable explained by variation in the independent variables in the model. Variable risk of production that can not be explained by the independent variables was $69 \%$. This is caused by other factors that are not included in the model, such as the risk of weather, water flow, turbidity, salinity, extreme ocean waves, market risk and other variables that are difficult to be measured.

T-test results indicate that the factors that influence the risk of production seaweed $E$. cottonii in South Sulawesi is an area of lots, number of seeds and bond distance of seeds. 
Area of lots negative effect on the level of $1 \%$. Regression coefficient of area of lots of 0.413 means an increase in the cultivation of the expansion of 1 percent would reduce the risk of production seaweed by 0.413 percent.

Increasing of usage of the number of seeds seaweed may reduce the risk of production. Regression coefficient value of 0.16 indicates that an increase in the number of seeds by $1 \%$ will reduce the risk of production of seaweed by 0.16 percent.

Bond distance of seeds significantly affects toward the risk of production seaweed $E$. cottonii. Regression coefficient of 0.11 indicates that an increase in distance bond of seeds of 1 percent would reduce the risk of production seaweed by 0.11 percent.

Table 3. Regression Estimates of Factors Affecting Risk of Production Seaweed E. Cottonii (Symptom-free multicolinearity and heteroscedasticity)

\begin{tabular}{lccc}
\hline \multicolumn{1}{c}{ Variable } & Coefficient & $\begin{array}{c}\text { Standard } \\
\text { errors }\end{array}$ & t-Statistics \\
\hline Constant & $-0.185^{* \star}$ & 0.088 & -2.101 \\
Area of lots & $-0.413^{* \star}$ & 0.322 & -1.283 \\
Seeds & $-0.158^{* \star *}$ & 0.030 & -5.321 \\
Bond distance of seeds & $-0.111^{* *}$ & 0.045 & -2.149 \\
Distance between the stretch rope & 0.069 & 0.046 & 0.570 \\
Labor & -0.122 & 0.052 & -0.723 \\
Age of farmers & 0.030 & 0.028 & 1.365 \\
Education of farmers & -0.025 & 0.018 & -1.176 \\
Experience of farmers & -0.003 & 0.012 & -1.136 \\
\hline $\mathrm{R}^{2}$ & 0.307 & & \\
$\mathrm{R}^{2}$ adjusted & 0.279 & & \\
\hline
\end{tabular}

Notes: ${ }^{*}{ }^{* * *},{ }^{k+*}$ are levels of significant at 1,5 and 10 percent

\subsection{Factors Affecting Productivity Seaweed E. cottonii having Considering Risk of Production}

The regression results of factors affecting productivity seaweed having considering risk of production using non-linier least squares are shown in Table 4. T-test results indicate that the factors that affect the productivity of seaweed E. cottonii after considering the risk of production are the area of lots, number of seeds, bond distance of seeds, labor, age, and experience of farmers. Area of lots a significant and positive at $1 \%$. Regression coefficient value of area of lots of 0.07 means that the increasing of the expansion in the cultivation of 1 percent will increase the productivity of seaweed $E$. cottonii 0.07 percent.

The increasing of amount of the seaweed seeds usage can increase productivity. Regression coefficient of 0.17 indicates that an increase in the number of seeds by $1 \%$ will increase the productivity of seaweed by 0.17 percent. Regression coefficient value of the distance bond of seed between the other seeds of seeweed is 0.21 means that the increasing the distance bond in seeds 1 percent will increase the productivity of seaweed E. cottonii by 0.21 percent. 
The usage of labor in the farming of seaweed E. cottonii give a rael and positive impact on productivity. Regression coefficient value of labor, of 0.18 means that the increased of labor usage by 1 percent would increase productivity of seaweed by 0.18 percent. Farmers' age give a real and negative impact on productivity. The regression coefficient of the age of farmer, of 0.18 indicates that the increasing age of farmers will reduce the productivity of seaweed E. cottonii of 0.04 percent. This is related to the period of reproductive age for farmers in managing their farming.

Farmers experience gives a positive and significant effect on productivity. The regression coefficient from the experience of farmers, of 0.02 indicates that an increase in the experience of farmers will increase the productivity of seaweed E. cottonii 0.02 percent. This is related to farmers' knowledge that are obtained while managing his farm that impact on the experience of farmers growing.

Table 4. Regression Estimates of Factors Affecting Productivity Having Considering Risk of Production Seaweed E. cottonii (Non-Linier Least Square)

\begin{tabular}{lccc}
\hline \multicolumn{1}{c}{ Variable } & Coefficient & $\begin{array}{c}\text { Standard } \\
\text { errors }\end{array}$ & t-Statistics \\
\hline Constant & $2.528^{* * *}$ & 0.586 & 4.315 \\
Area of lots & $0.073^{* * *}$ & 0.027 & 2.673 \\
Seeds & $0.168^{* * *}$ & 0.072 & 2.330 \\
Bond distance of seeds & $0.211^{* * *}$ & 0.030 & 7.001 \\
Distance between the stretch rope & -0.043 & 0.047 & -0.921 \\
Labor & $0.179^{* * *}$ & 0.033 & 5.341 \\
Age of farmers & $-0.043^{*}$ & 0.023 & -1.893 \\
Education of farmers & 0.000 & 0.013 & 0.033 \\
Experience of farmers & $0.022^{* *}$ & 0.009 & 2.342 \\
\hline & Weighted Statistics & \\
\hline $\mathrm{R}^{2}$ & 0.887 & \\
$\mathrm{R}^{2}$ adjusted & 0.882 & \\
\hline
\end{tabular}

Notes: ${ }^{*},{ }^{* *},{ }^{* * * *}$ are levels of significant at 1, 5 and 10 percent.

\subsection{Comparison of Estimation Results of Production Function of Cobb-Douglas and Production Function of Just-Pope on Farming Seaweed E. cottonii}

Based on the data in Table 5 (columns I, III and IV) can be explained that the second application to the function of have different implications related to the result of the estimation of regression coefficients, the usage of input variables and input variables that affect the productivity of seaweed.

Values of regression coefficient have significant affect the productivity of seaweed $E$. cottonii on the Cobb-Douglas production function decreased after considering the risk of production (column IV). The decline in the value of the regression coefficient indicates that there are risk factors of production to be borne by farmers in an effort to improve the productivity of seaweed. Related to the usage of inputs that each increase in the use of inputs $(\mathrm{Xi})$ will always increase the output variance $[\mathrm{V}(\mathrm{y})]$ or the risk of production, the results of the analysis are shown in Table 5 (column III), strengthening 
the assumption of Just and Pope (1979), that the increase usage of the number of inputs to a certain extent it will reduce the risk of production.

Input variables that affect productivity, the estimation Cobb-Douglas production function; area of lots, the age of farmers and experience of farmers do not affect the productivity of seaweed. In contrast to the results of the estimation of the Just-Pope production function (column IV); area of lots, age and experience of farmers affect the productivity of seaweed. This indicates that the presence of risk factors that must be borne by the farmer cause that in addition to the input number of seeds, bond distance of seeds and labor, the productivity of E. cottonii seaweed is also influenced by the area of lots, the age and experience of farmers.

Table 5. Factors Affecting Productivity by Not Considering Risk (Cobb-Douglas Model) and Considering Risk of Production (Just-Pope Model) on Farming Seaweed E. cottonii

\begin{tabular}{|c|c|c|c|c|}
\hline \multirow{4}{*}{ Variable } & $\begin{array}{c}\text { Cobb- } \\
\text { Douglas }\end{array}$ & \multicolumn{3}{|c|}{ Just-Pope } \\
\hline & OLS & NLS (before) & OLS (risk) & NLS (after) \\
\hline & I & II & III & IV \\
\hline & coefficient & coefficient & coefficient & coefficient \\
\hline \multirow{2}{*}{ Constant } & $3.460^{* *}$ & $2.425^{\text {*** }}$ & $-0.185^{\star * *}$ & $2.528^{* * *}$ \\
\hline & $(0.293)$ & $(0.057)$ & $(0.088)$ & $(0.586)$ \\
\hline \multirow{2}{*}{ Area of lots } & 0.028 & $0.090^{* * *}$ & $-0.413^{* *}$ & $0.073^{* * *}$ \\
\hline & $(0.021)$ & $(0.019)$ & $(0.322)$ & $(0.027)$ \\
\hline \multirow{2}{*}{ Seeds } & $0.362^{* \star *}$ & $0.043^{* * *}$ & $-0.158^{* * *}$ & $0.168^{* * *}$ \\
\hline & $(0.088)$ & $(0.009)$ & $(0.030)$ & $(0.072)$ \\
\hline \multirow{2}{*}{ Bond distance of seeds } & $0.241^{* * *}$ & $0.109^{* * *}$ & $-0.111^{* *}$ & $0.211^{* * * *}$ \\
\hline & $(0.060)$ & $(0.021)$ & $(0.045)$ & $(0.030)$ \\
\hline \multirow{2}{*}{ Distance between the stretch rope } & 0.113 & -0.046 & 0.069 & -0.043 \\
\hline & $(0.094)$ & $(0.034)$ & $(0.046)$ & $(0.047)$ \\
\hline \multirow{2}{*}{ Labor } & $0.226^{* \star *}$ & $0.211^{* * *}$ & -0.122 & $0.179^{\star \star *}$ \\
\hline & $(0.041)$ & $(0.023)$ & $(0.052)$ & $(0.033)$ \\
\hline \multirow{2}{*}{ Age of farmers } & 0.022 & 0.005 & 0.030 & $-0.043^{*}$ \\
\hline & $(0.059)$ & $(0.017)$ & $(0.028)$ & $(0.023)$ \\
\hline \multirow{2}{*}{ Education of farmers } & 0.051 & 0.012 & -0.025 & 0.000 \\
\hline & $(0.032)$ & $(0.010)$ & $(0.018)$ & $(0.013)$ \\
\hline \multirow{2}{*}{ Experience of farmers } & -0.029 & -0.008 & -0.003 & $0.022^{* *}$ \\
\hline & $(0.025)$ & $(0.008)$ & $(0.012)$ & $(0.009)$ \\
\hline$\overline{\mathrm{R}^{2}}$ & 0.903 & 0.907 & 0.307 & 0.887 \\
\hline $\mathrm{R}^{2}$ adjusted & 0.899 & 0.903 & 0.279 & 0.882 \\
\hline
\end{tabular}

Notes: ${ }^{*}{ }^{* *},{ }^{* * *}$ are levels of significant at 1, 5 and 10 percent, respectively

Figures in parentheses are the standard errors

\section{Conclusion}

The determinants of productivity of seaweed E. cottonii are number of seeds, bond distance of seeds and labor. Area of lots, number of seeds, and the bond distance of seeds reduce the risk of production. Factors that affect the productivity after considering the risk of production is the area of lots, number of seeds, bond distance of seeds, labor, age, and experience of farmers. Values of regression coefficient have 
significant affect the productivity of seaweed (Cobb-Douglas model) tend to decrease after considering the risk of production (Just-Pope model).

\section{Acknowledgements}

The writer wishes to express her gratitude to Pangkep State Polytechnic of Agriculture DIPA research grant for funding this research.

\section{References}

Azwir, 2011. Analisis Finansial dan Efisiensi Produksi Usahatani Rumput Laut Di Kota Kendari Sulawesi Tenggara. Tesis Ekonomi Pertanian. Universitas Gadjah Mada, Yogyakarta.

Debertin, D. L., 1986. Agricultural Production Economics. Second Edition. Mc.Graw Hill Inc. New York

Gujarati, D., 1995. Basic Econometrics. Third Edition. McGraw-Hill International Editions

Hayami, Y., and V. W. Ruttan, 1985. Agricultural Development : An International Respective. The Jhon Hopkins Press. Baltimore. London

Hidayati W., Sulkifli, and Kasim N., 2014. Analisis Kelayakan Finansial dan Sensitivitas Usahatani Rumput Laut Eucheuma cottonii di Sulawesi Selatan." Jurnal Lutjanus Teknologi Perikanan dan Kelautan, 19 (1): 18-20.

Just, R. E., 1974. "An Investigation of the Importance of Risk in Farmers' Decision." American Journal of Agricultural Economics, 21 (2): 14-25.

Just, R. E., 1975. Risk Response Models and Their Use in Agricultural Policy Evaluation. American Journal of Agricultural Economics, 57 (2): 836-843.

Just, R., and Pope, R. D., 1979. Production Function Estimation and Related Risk Considerations. American Journal of Agricultural Economics, 6 (2): 276-284.

Kay, R.D., 1981. Farm Management, Planning, Control and Implementation. International Student Edition. Mc Graw-Hill International Book Company. New York.

Kementerian Kelautan dan Perikanan Provinsi Sulawesi Selatan, 2012. Laporan Statistik Perikanan Sulawesi Selatan Tahun 2011. Dinas Kelautan dan Perikanan Provinsi Sulawesi Selatan, Makassar

Nicholson, W., 1998. Microeconomic Theory: Basic Principles and Extentions. Seventh Edition. The Dryden Press. Foft Worth

Nurdjana, L. M., 2006. Pengembangan Budidaya Rumput Laut Di Indonesia. Makalah pada Diseminasi Teknologi dan Temu Bisnis Pengembangan Budidaya Rumput Laut serta Pemasarannya. Makassar, September 11

Pindyck, R..S., and D. L. Rubinfeld, 2001. Econometric Models and Economic Forecasts. McGraw-Hill. New York.

Roumasset, J. A., 1976. Risk Aversion, Indirect Utility Function Market Failure, In : Roumasset, J. A., Boussard, J. M., Singh, I. (eds) Risk and Uncertainty an Agriculture Development. Agriculture Development Council. New York.

Senjawati, N. D., 2008. Analisis Risiko Usahatani Berbasis Padi Di Kabupaten Kulon Progo. Disertasi. Pasca Sarjana Universitas Gadjah Mada, Yogyakarta

Widodo, Sri, 2006. Strategi Mengatasi Rawan Pangan: Seminar Nasional Forum Komunikasi Kebijakan dan Pusat Studi Asia Pasifik-UGM. Yogyakarta, December 1-3 
Yotopoulus, P.A., and J.B. Nugent, 1976. Economics of Development: Empirical Investigations. Harper and Row Publishers. New York

Zakirin, M., Yurisinthae, E., and Kusrini, N., 2013. Analisis Risiko Usahatani Padi pada Lahan Pasang Surut di Kabupaten Pontianak. Jurnal Social Economic of Agriculture, 2 (1): 75-84. 